\title{
The Dubious Representations of Histories in Running in the Family by Michael Ondaatje
}

\section{Michael Ondaatje'nin Running in the Family Eserinde Tarihin Müphem Temsilleri}

\author{
Ersoy GÜMÜş'
}

'Dr., Istanbul University, School of Foreign Languages, Istanbul, Turkey

ORCID: E.G. 0000-0002-3919-336X

\section{Corresponding author:}

Ersoy GÜMÜş,

İstanbul Üniversitesi, Yabancı Diller Yüksekokulu, Kirazlı Mescit Sokak, No: 31 PK: 34116 Süleymaniye, Fatih, İstanbul, Türkiye

E-mail: ersoygumus@yahoo.com.tr

Submitted: 03.12.2020

Revision Requested: 15.02.2021

Last Revision Received: 28.02.202 Accepted: 30.04.2021

Citation: Gumus, E. (2021). The dubious representations of histories in Running in the Family by Michael Ondaatje. Litera, 31(2), 547-564

https://doi.org/10.26650/LITERA2020-835634

\begin{abstract}
Coined by Stephan Greenblatt in 1980s, new historicism flourished as a literary approach which presents new perspectives on the perception of history. It basically challenges the traditional understanding of history which claims that history records and interprets past events objectively in a chronological order. New historicists, therefore, centre on the representations of history, not the history itself as they assert that there is not a single objective history, but there are multiple subjective histories. As new historicism claims that history may be represented only subjectively, truths for new historicists are always unstable. Thus, new historicism states that history is not regarded as a grand narrative dictating a single meaning, truth or essence. The purpose of this article is to examine how history is represented in Michael Ondaatje's Running in the Family, which is described as a fictionalised autobiographical memoir, from a new historicist perspective. As a Canadian diasporic writer returning to Sri Lanka, his birth place, after a long absence, Ondaatje reconstructs his family history by depending on memories, gossip, and rumour all of which are unreliable and subjective. Similarly, while reconstructing Sri Lankan history, the narrative is based on colonial discourse which fantasies or even mythologizes the island. Therefore, this article attempts to demonstrate how history is reconstructed and narrated in subjective ways which bring out multiple histories by focalising the unreliable memories and colonial discourse.
\end{abstract}

Keywords: New Historicism, Michael Ondaatje, Running in the Family, representation of history, memory

\section{öz}

Yeni tarihselcilik, 1980li yıllarda Stephan Greenblatt tarafından öne sürülen ve tarih algısına yeni bakış açıları sunan bir edebi yaklaşımdır. Esasen bu yaklaşım, tarihin geçmiş olayları nesnel olarak kronolojik bir sıra içerisinde kayıt altına alıp yorumladığını iddia eden geleneksel tarih anlayışına karşı çıkmaktadır. Bu yüzden, tek bir nesnel tarihin olmadığını ancak birçok öznel tarihin olduğunu kabul ettikleri için yeni tarihselciler tarihin kendisi üzerinde değil, tarihin temsilleri üzerinde yoğunlaşırlar. Yeni tarihselcilik tarihin sadece öznel olarak yansıtıldığını iddia ettiği için, yeni tarihselciler için hakikatler her zaman değişkendir. Bu yüzden yeni tarihselcilik tarihin tek bir anlam, hakikat ya da öz dikte eden bir üst anlatı olarak kabul edilmediğini belirtir. Bu makalenin amacı, Michael Ondaatje'nin kurgulanmış otobiyografik anı 
olarak tarif edilen Running in the Family adlı eserini yeni tarihselci bir bakış açısıla incelemektir. Uzun bir yokluktan sonra doğum yeri olan Sri Lanka'ya dönen Kanadalı diasporal bir yazar olarak Ondaatje, hepsi güvenilmez ve öznel olan anılara, dedikodulara ve söylentilere bağlı olarak kendi aile tarihini yeniden düzenler. Benzer bir şekilde Sri Lanka tarihini yeniden şekillendirirken anlatı, adayı fantezileştiren hatta mitleştiren kolonyal söyleme dayanır. Bu yüzden bu makale, tarihin birçok tarihi ortaya çıkaran öznel yollarla nasıl yeniden şekillendirildiğini ve anlatıldığını güvenilmeyen anılar ve kolonyal söyleme odaklanarak göstermeye çalışmaktadır.

Anahtar Kelimeler: Yeni Tarihselcilik, Michael Ondaatje, Running in the Family, tarihin temsili, bellek 


\section{Introduction}

From the traditional perspective, history is perceived as the record of the past events in a chronological order. It is regarded as an objective record of past occurrences. For many conventional historians, history tenders a series of events which are linear and objective. They elaborate that history narrates the events progressively in a linear way and it is possible to present the historical events objectively. Furthermore, they claim that the facts about these historical occurrences have a causal relationship which signifies that an event has resulted in another event which has similarly led to a third event. However, the perception and interpretation of history have gone through a dramatic change after the birth of new historicism. Although both traditional historians and new historicists assent to the key significance of historical context while reading literary works, they depart from each other in many crucial aspects.

The first and the most important difference between old and new historicists is that the latter does not believe in the "objectivity and permanence" of history (Booker, 1996, p. 135). Reiterating the same view, Brannigan rejects the dominant idea of the $19^{\text {th }}$ century which regards history as "the description of knowable past or as the empathetic recreation of that past" (Brannigan, 1998, 29). Therefore, from a new historicist viewpoint, history never presents historical events objectively. On the contrary, history is the representation of subjective realities which are not stable or permanent but as a state of flux. Additionally, new historicists stress the idea that history is a process in which the past "is constructed or invented" as the perspectives of historians are affected either consciously or unconsciously by innumerable factors such as the age and community they live in (Booker, 1996, p. 135). As a result, literary works are "inseparable from the social and political contexts in which they are embedded" (Brannigan, 1998, p. 68). Therefore, new historicists repudiate the accessibility of clear facts of history except the basic ones such as the place and the time of incidents. According to new historicists, history is seen as:

[...] consisting of very diverse configurations of beliefs, values and trends, often coming into conflict and contradiction with each other [...] (They) question and examine the assumptions behind their own interests in the past, and ground their practices of historical interpretation in the explanation of political pressures in the present. (Brannigan, 1998, p. 31) 
Thus, new historicists believe that it is impossible to present facts, yet what is possible is the presentation of interpretation. Another important difference between old and new historicism is unearthed by the phrase "the archival continuum" which clarifies that new historicism is not historical but historicist (Barry, 2009, p. 152). The term historicist connotes that new historicism focalises how history has been recorded or represented in documents as the historical occurrences are eternally lost and they are impossible to be recovered. Thus, it is claimed by the new historicists that "the word of the past replaces the world of the past" because not only events but also attitudes related to the past are merely in the form of writing today (Barry, 2009, p. 153). Further, new historicists have admitted Derrida's view of deconstruction postulating that there has been nothing well worth considering outside the text which asserts the past can only become available through textualised works. Barry argues that these textualised works are "thrice processed" as they are deeply affected firstly by "ideology or discursive practices" which were dominant in the period they were penned, secondly by those which are dominant in the period they are read, and finally by the language web which has been distorted (Barry, 2009, p. 153). Therefore, whatever the text presents is remade or represented which leads new historicists to rely on the idea that neither literary nor historical texts may be interpreted objectively or reliably. Another reason which makes the reliable interpretation of these texts impossible is the futility of "objective analysis" (Tyson, 2006, p. 283). In contrast to the view of traditional historians, new historicists believe that history is not a parade which is strictly ordered. Any historical event is an output of the culture where it occurs and in return it influences the culture as well. Thus, a historical event is not only formed by its culture but it also forms the culture in where it occurs. As a result, although historians claim to be objective, their cultures, personal ideologies, and experiences impact their interpretations and representations of historical events which results in a complex and unreliable process. Moreover, even though historical events assuredly derive from some causes, new historicists contend that these causes are not certain but complex which makes the objective analysis of these events more difficult.

According to new historicists, old historicism merely provides a simple background or context in which literature reflects sole history. On the contrary, new historicists unite literature with history in order to examine how they affect each other. They admonish that it is not possible to clearly state what people believed in a certain age or what the view point of that age was. Guerin firmly states that according to new historicists "history is as complex, nuanced and unstable as literature" as it only represents 
"a set of cultural discourses" which may be interpreted as a literary work (Guerin, 2011, p. 133). He also adds that history is shaped by literary works "in an ongoing cycle of mutual relationship" (Guerin, 2011, p. 133). Similarly, new historicists working with deconstruction tend to analyse literature by reckoning on multiple meanings, discrepancies, and even some omissions in history which paves the way to interrogating the facts of both history and literature.

The term new historicism is believed to be coined by Stephen Greenblatt, a Renaissance scholar, whose thoughts have been deeply influenced by Michael Foucault. Drawing on Foucault's ideas, Guerin claims that new historicists have established the thought of the "totalising" role of culture which may be observed in the literary works of that culture, and he called it the "episteme" (Guerin, 2011, p. 133). Similarly regarding Foucault's views, Guerin claims that due to the persistence of some dominant ideas affecting or shaping reality from the past to the present, history runs within universal ideas. In other words, in Foucault's understanding, history does not consist of the sameness which indicates that it is somehow different from what it seems to be. Thus, Foucault argues:

[...] in every society the production of discourse is at once controlled, selected, organised and redistributed according to a certain number of procedures, whose role is to avert its powers and its dangers to cope with chance events [...] (Foucault, 1986, p. 149)

According to Foucault, power is a specific discursive institution which is closely knit to knowledge; hence, power and knowledge complement one another. Therefore, the production of power recreates the social system of which discourse is regulated within "the will to knowledge" (Foucault, 1986, p. 151). The new historicists deal with the representations of power which are disguised in texts because these texts are the representations of the history of the time in which they are written. As a result, they are directly or indirectly influenced by the mechanisms of power and they do not represent temporal truths in history. Moreover, Guerin describes history as "a form of social oppression told in a series of ruptures with previous ages; [...] discontinuous, riven by fault lines that must be integrated into succeeding cultures by the epistemes of power and knowledge" (Guerin, 2011, p. 133). Although the contemporary era has been dominated by a "complex master narrative", it is closely linked with the earlier ages and generations as well as succeeding them (Guerin, 2011, p. 133). 
Foucault identifies societies' expectations as the results of the dominant culture; thus, there cannot be any essence belonging to the human mind. Contrarily, it is the "outer knowledge or history" which develops "the self as a knowledge discourse that produces what it seems only to describe" (Guerin, 2011, p. 133). Therefore, there are only dominant ideologies or discourses, not genuine truth or texts. For Foucault, modern society is like Panopticon, which is a prison model with a central tower in the centre where the inmates are under constant surveillance without being able to detect their guards. In order to explain the significance of Panoptican, Foucault writes:

Hence the major effect of the Panopticon: to induce in the inmate a state of conscious and permanent visibility that assures the automatic functioning of power. So to arrange things that the surveillance is permanent in its effects, even if it is discontinuous in its action; that the perfection of power should tend to render its actual exercise unnecessary; that this architectural apparatus should be a machine for creating and sustaining a power relation independent of the person who exercises it; in short that the inmates should be caught up in a power situation of which they are themselves the bearers. (Foucault, 1995, p. 201)

Similarly, in modern society people's ideologies or attitudes can be not only observed closely but also regulated and disciplined constantly which ultimately results in a society observing itself for any aberrant thoughts or practices. Likewise, new historicists, inspired by Foucault's sharp "discourse of hegemony", assert that history is ideologically or by reference to Foucault discursively remade and constructed.

As a reflection of the new historicist thought which problematises the liaison between truth and history, this paper deals with the dubious representations of history or histories as a master narrative by paying close attention to documents, memory, and narrative techniques that will be examined in Michael Ondaatje's Running in the Family. Thus, this paper aims to offer an interpretation to the aforementioned work through an analysis of both private and public history, the history of Ondaatje family, the history of Sri Lanka as a colonised country by dwelling on the memory, gossip, rumour, and colonial discourse all of which show that it is possible to narrate history from not only multiple but also subjective perspectives which make history unreliable. 


\section{Reconstruction of Histories through Unreliable Memories and Storytelling}

Michael Ondaatje is a Sri Lankan diasporic author who lives in Canada. In the novel Running in the Family, he narrates his two journeys (one in 1978 and the other in 1980) to his birth island after twenty five years of absence Ondaatje's narrative has been evaluated respectively as "an experimental autobiography" (Solecki, 2003, p. 141), a "fictionalised memoir" (Davis, 1996, p. 267), and a "travel memoir" (Huggan, 1995, p. 118). Therefore, it would not be wrong to approach Ondaatje's Running in the Family as a memoir which includes the writer's own fragmented childhood memories, as well as his siblings' memories, and the narratives related to his parents' generation. Similar to the new historicists who dwell on multiple truths, the novel represents multiple truths deriving from unreliable and clashing memories of Ondaatje and other characters in the novel.

The unreliability of memories as a tenet of new historicism is seen from the very beginning of the novel. It is clear that there are different truths and Ondaatje comes across these multiple truths while rediscovering his family past. As he journeys back after a very long time, he not only remembers but also distorts or misinterprets multiple memories which reconstruct an unreliable or perplexing history for the reader. Throughout the novel Ondaatje refers to the island Ceylon, the colonial name which was used when the Ondaatje family was still there, though it took its new name Sri Lanka in 1972. His continual reference to the island by its colonial name signifies Ondaatje's hope to revisit and see the island as it was in his childhood. This also demonstrates that his links with today's Sri Lanka is tenuous so Ondaatje grounds on vague childhood memories.

What inspires Michael Ondaatje to journey back after such a long dispersion is a haunting dream which drives Ondaatje to desire to learn more about his dead father. Thus, especially the sections which are devoted to Mervyn, the author's father, examine the interrelationship between facts and gossip or imaginative reconstructions. Gossip, which is a significant textual preoccupation and force in life is also central to Ondaatje's work. As gossip subtly differs from person to person, it might be true or false, or it might be invented for a specific purpose. However, it is never questioned if it is documented or not. Therefore, gossip reveals multiple histories all of which describe Mervyn from a different perspective. Mervyn Ondaatje emerges as a charismatic man, a reckless and 
irresponsible young man, a problematic son, an attractive suitor, and a mocking husband in different anecdotes (Ondaatje, 1982, p. 174). These various stories which are legendary and even mythic, overshadow the real Mervyn. As a result, the author is left as an inquisitive figure asking; "Where is the intimate and truthful in all this? Teenager and Uncle? Husband and Lover?" (Ondaatje, 1982, p. 54). After realising that the memories or gossip told by Mervyn's contemporaries cannot construct the father portrait that the author yearns for, he switches to the memories of his siblings and Mervyn's closest companions. While Ondaatje's siblings recollect stories about Mervyn's drunkenness which always caused distress and unhappiness, Mervyn's close friends comment that Mervyn "was an utterly charming man, always gracious" (Ondaatje, 1982, p. 175). However, by adding that they did not know "what he was like when he was drunk" (Ondaatje, 1982, p. 175), they confront Ondaatje with disquieting memories. Furthermore, Ondaatje and his brother Christopher, who has also written an autobiography, have some sharply contrasting views about Mervyn. Christopher refers to his own autobiography "as a corrective to Running" (Bolton, 2009, p. 222) as he recites his brother's autobiography as "a love letter to the father Michael never knew" and places himself being "deeply involved with that man ...grappling with his demons (Adams, 2000 , p. 122). Being convinced by various gossips and stories, Michael Ondaatje understands that he can never reach an objective truth about his father. The author writes;

There is so much to know and we can only guess. Guess around him. To know him from these stray actions I am told by those who loved him. And yet, he is still one of those books we long to read whose pages remain uncut. We are still unwise. (Ondaatje, 1982, p. 200)

Put briefly, Ondaatje gradually realises that all the stories and gossip he unearths during his journeys make his father and family history more complicated and impossible to grasp and he explains "gossip tells us in the end nothing of personal relationships" (Ondaatje, 1982, 53). Finally, he draws an analogy between his father and "the north pole", both of which are too far to reach and know exactly (Ondaatje, 1982, p. 172).

While planning his journey, Ondaatje examines various maps of the island; however, none of the maps he consults correspond with Ceylon as he remembers. Thus, he pores over his memory map so that he can rediscover the places he hopes to repossess. When he is back in Ceylon, he visits these places which shape his memories. Though some 
of them are compatible with Ondaatje's memories, he feels unsettled because of the others which are somehow different. One of the places that unsettles Ondaatje is Rock Hill which is the "family home" built by Ondaatje's paternal grandfather "on a prime spot of land right in the centre of the town of Kegalle" (Ondaatje, 1982, p. 55). The discrepancy that disappoints Ondaatje is given as;

What to us had been a lovely spacious house was now small and dark, fading into the landscape. A Sinhalese family occupied Rock Hill. Only the mangosteen tree, which I practically lived in as a child during its season of fruit, was full and strong. (Ondaatje, 1982, p. 59; emphasis added)

For Ondaatje, the sole object which survives as in his memories is a tree. Further, Rock Hill, which was splendiferous in Ondaatje's memories, has turned into a "depressed garden" (Ondaatje, 1982, p. 60). Focusing on the ambiguity in the representation of one's own history, Foucault writes:

[...] this historicity is ambiguous. Since man posits himself in the field of positive knowledge only in so far as he speaks, works and lives, can his history ever be anything but inextricable nexus of different times, which are foreign to him and heterogeneous in respect of one another? (Foucault, 1991, p. 369)

Foucault elucidates that as the rememberer, man does not have a single history in his mind; contrarily, he experiences different, inseparable, and discontinuous histories and memories which result in "[...] what lives in human life, is man himself" and he "no longer has any history" (Foucault, 1991, p. 369). Therefore, reality seems to have disappeared in Ondaatje's mind and he creates a completely different history. As a result of this discontinuity with the past, after visiting Rock Hill, Ondaatje clearly understands that the past will remain uncertain. What is more disquieting for Ondaatje is the clash between his own and his older sister Gillian's memories. While Ondaatje reminisces about Rock Hill as an unperturbed home where they spent their happy and idyllic days, Gillian's memories bring their troubled childhood to the fore as she reminds their alcoholic father; "Gillian remembered some of the places where he hid his bottles. Here she said, and here" (Ondaatje, 1982, p. 59). After perceiving the contrast between his memories and the actual Rock Hill and Gillian's memories, Ondaatje understands that his memories may be inaccurate and unreliable. Further, these discrepancies testify 
the new historicist principle advocating the coexistence of multiple truths and Marta Bladek claims that although Ondaatje hopes to revisit the history through his journey, his memories are so fragmented that they "will always prevent him from being able to intimately know the past" (Bladek, 2012, p. 398).

Ondaatje, returning to Ceylon in the hope of revisiting his past, also intends to animate his ancestors' lives which have been surrounded by silence. For this purpose, storytelling and story collecting becomes a tool of mediation between the past and present as Ondaatje believes that the past which is boxed in a place may be re-entered, known, and narrated by means of stories: "...I would be travelling back to the family I had grown from - those relations from my parents' generation who stood in my memory like frozen opera. I wanted to touch them into words" (Ondaatje, 1982, p. 22). When he gets back to his family home, other familiar places, and people that he was close to twenty five years ago, Ondaatje seeks for facts through stories which he himself cannot recall. However, while collecting stories, Ondaatje realises that they are merely the reproduction of the past events which had taken place long before. Additionally, they "tie loose ends, order fragments and fill in gaps" (Bladek, 2012, p. 398). Especially “Eclipse Plummage", the section that centres on Lalla, Ondaatje's grandmother, includes three sequential chapters in which Ondaatje records his family history. In the first of these chapters "Lunch Conversation", which narrates the informal gatherings of people who know Lalla, each guest tells a personal story with a specific incident. Mislaid by the cacophony of recollections, Ondaatje repeatedly asks questions about stories to clarify; "Wait a minute, wait a minute! When did all this happen? ... when is this happening?" (Ondaatje, 1982, p. 107). However, the responses reveal time shifts in the stories "One when your mother was nine. Then when she was sixty-five" (Ondaatje, 1982, p. 108) which make these recollections blurry. Moreover, as the family history is reconstructed in the stories of various guests, there are some gaps which Ondaatje cannot fill; thus, he implies that there are different histories; "there seems to be three different stories that you're telling" (Ondaatje, 1982, p. 108). Therefore, both shifting time and different accounts of stories make time and history indefinite and unreliable. At the end of this chapter, Ondatje suggests that eventually he has been able to arrange all the fragments into an intelligible story as the chapter concludes with his own narration which once more reconstructs the memories he has listened to. Similarly, in the second chapter "Aunts", Ondaatje relies heavily on the recollections of his older aunts; "...they knit the story together, each memory a wild thread in the sarong" (Ondaatje, 1982, p. 110). Although these stories narrated by aunts are enticing, they are the representation of 
fragmented and dispersed memories which Ondaatje describes as "dark rooms with various kinds of furniture" (Ondaatje, 1982, p. 110) and they become only intelligible after being organised by Ondaatje, which emerges as another reproduction of memories. Finally, in the third chapter, which is entitled "The Passions of Lalla", Ondaatje claims that Lalla, who was "hauled away by an arm of water" (Ondaatje, 1982, p. 118), died of a monsoon. However, once again contesting Ondaatje's view, Christopher alleges that Lalla died because of alcohol poisoning (Gudmundsdottir, 2003, p. 154). Therefore, two siblings offer alternative histories, not an authentic history. New historicism, according to Greenblatt, "does not posit historical processes as unalterable and inexorable, but it does tend to discover limits or constraints upon individual intervention. Actions that appear to be single are disclosed as multiple" (Greenblatt, 1990, p. 221). As Greenblatt refers here, in Ondaatje's memoir there is not a single, universal, and objective history which can be viewed as a grand-narrative, yet there are private, subjective, and multiple histories recreated by different characters and Ondaatje himself.

As the host who has invited the guests to share their memories with him, Ondaatje assists the progress of their memories and more importantly he transforms these incomplete and inaccurate memories into narrative. Ondaatje, taking an active role in conveying the past, ponders over the interaction between storytelling or story collecting and remembering which is unavoidably used as a means of access to history. Moreover, the unreliability of memories and stories is once again depicted in an afternoon when Aunt Phyllis, Uncle Nad and some other guests gather;

... intricate conversations will begin again. [...] we will trade anecdotes and faint memories, trying to swell them with the order of dates and asides. [...] No story is ever told once. Whether a memory or funny hideous scandal, we will return to it an hour later and retell the story with additions and this time a few judgements thrown in: In this way history is organized. (Ondaatje, 1982, p. 26)

Ondaatje highlights that although their conversations are continuously engaged in the past, they are malleable and elusive. Accordingly, Ondaatje's narrative is largely reconstructed by "long lists of confused genealogies and rumour" (Ondaatje, 1982, p. 206). Ultimately having faced with the insurmountable extent of finding out the past, Ondaatje realises that the past is neither rigidly captivated in any place nor can be totally transmitted or understood by memories and stories. Therefore, he expresses 
that at certain times throughout our life "during certain hours, at certain years in our lives, we see ourselves as remnants from the earlier generations that were destroyed. So our job becomes... with "the mercy of distance" write the histories" (Ondaatje, 1982, p. 179).

The narrative techniques that Ondaatje uses in the novel also remark the unreliability of the text. In addition to the narrator, the work includes many first person voices and stories. Particularly in the chapter entitled "Dialogues" there are many unnamed first person voices all of whom reconstruct a personal story. Also, throughout the text Ondaatje suddenly moves from the first person narration to the third to produce a feeling that the book has been written not by a single writer but by a community and Ondaatje advocates this impression by writing that "a literary work is a communal act" (Ondaatje, 1982, p. 205). Moreover, towards the end of the work, he warns the reader that what he has written "is not a history but a portrait or "gesture"' (Ondaatje, 1982, p. 206). The term "portrait" may imply that it is a representation and not a frozen image as photographs display and "gesture" possibly refers to an attitude which aims at expressing himself. Although multiple voices narrating different stories in the work supply readers with multiple perspectives, none of them can be credited with presenting a reliable or superior truth.

\section{Public Histories through Colonial Discourse}

In the novel, which is a multilayered literary work (autobiographical, historical, and personal), the history of Sri Lanka as a colonial island intersects with the history of Ondaatje's family. Throughout the novel, Ondaatje attempts to offer an alternative history of the former colony Sri Lanka from a postcolonial perspective. The fantasised views of various colonisers of Sri Lanka and recreated histories of Ondaatje's family have been clustered in Ondaatje's narrative. Through this way, Ondaatje denaturalises truths in the historical background by integrating them with both fantasised views of colonisers and reminisced personal history. Thus, Ondaatje's and other characters' memories and perspectives of various colonisers and foreign visitors carry a major significance in shaping the history. Louis Montrose, a significant new historicist literary critic, makes use of the motto "the historicity of texts and the textuality of history" (Montrose, 2000, p. 781) to indicate the hazy relation between fiction and history which ultimately ends up at the subjective history. He defines his motto as following; 
By the historicity of texts, I mean to suggest the cultural specificity, the social embedment, of all modes of writing - not only the texts in which we study them. By the textuality of history, I mean to suggest, firstly, that we can have no access to a full and authentic past, a lived material existence, unmediated by the surviving textual traces of the society.... Secondly, that those textual traces are themselves subject to subsequent textual mediations when they are construed as the "documents" upon which historians ground their own text, called "histories". (Montrose, 2000, p. 781)

According to him, it is hardly possible to gain access to an authentic past through history as those who pen documents or texts touch, influence, or recreate them because of social processes. He also puts forward that even while reading a specific historical text, each reading may prove a different meaning; thus, the meaning is always unstable. Briefly, Montrose assumes that there is not a unified history that is identical for each and every reader and age. Contrarily, there are different histories of different historians which signify various subjective histories (Montrose, 2000, p. 781). Similarly, Hutcheon writes that both fiction and history derive from "discourses; human constructs, signifying systems" and also expresses that there is a blurry line between fiction and history and it is also the link between public and private histories as they affect each other (Hutcheon, 1989, p. 93).

The novel intertwines the writer's personal history with the colonial experiences of the island while reconstructing and chronicling the histories of both parties. Even while still in Canada preparing for his journey back, Ondaatje relies on maps to find some routes to Ceylon. However, as all these maps have been drawn by those who had come ashore to capture the riches of Ceylon or the island itself, he describes them as "...false maps. Old portraits of Ceylon. The results of sightings, glances from trading vessels, the theories of sextant" (Ondaatje, 1982, p. 63). Also, the shapes in these maps differ so much that they look like translations of scholars from unrelated scientific fields. Moreover, the old maps transmit almost no factual truth and Ondaatje highlights that they "reveal rumours of topography, the routes for invasion and trade, and the dark mad mind of travellers' tales appear throughout Arab and Chinese and medieval records" (Ondaatje, 1982, p. 64). As the colonisers have attempted to list Ceylon's elusiveness while searching ways to occupy it, these maps depict Ceylon's colonial history. The significance of these diversified maps is also highlighted by Edward Said who describes them as, 
[...] imaginative geography-the invention and construction of a geographical space called the Orient, for instance, with scant attention paid to the actuality of the geography and its inhabitants-but also on the mapping, conquest, and annexation of territory [...] (Said, 2000, p. 181)

Said emphasises that both map making and journeys to discover new and multiple geographies were a basic part of a colonial project which aimed to control and posses the land. Map making which is also regarded as a tool of not only "survey" but also "surveillance" in colonial period also reflects both cultural presumptions and the goals of those who make colonial maps (Smyth, 2006, p. 25). These maps demonstrate "no pure truth, only ideologies" (Guerin, 2011, p. 133). To put it differently, they delineate "explorers' perception and understanding of the unfamiliar island...shaped by the political, intellectual and cultural context they themselves inhabited" (Bladek, 2012, p. 393). Therefore, it becomes clear that similar to the relation between memories and historical events, maps and authentic locations reveal no straight correspondence. In addition to maps, Ondaatje attempts to reach an accurate history by examining local archives, including photographs, reviewing newspapers, and researching journal entries. However, he is unable to capture the past entirely and he states that "truth disappears with history" (Ondaatje, 1982, p. 53).

Foucault believes that there are no facts, but only possible interpretations of facts and he regards knowledge as power which is, for Foucault, a network of different forces that shape and reshape not just individuals but also institutions and discourses. Dwelling on the influence of dominant power and discourse on the truth, Zivkovic writes;

...old humanist notions of truth, self, the world and meaning must be discarded as falsehoods and illusions of imperialist, capitalist culture. They [contemporary theories] tell us there can be no fixed or true identity, no origin or original, no singular author. There is no ultimate knowledge, representation is no longer a matter of veracity or accuracy but merely of competing discourses. Notions of authenticity or truth are outdated and the most basic factor in human motivation is power. (Zivkovic, 2004, p. 99)

Similarly, in Running in the Family Sri Lanka is formulated and represented through colonial discourse which is detailed by Said that colonial writing displays colonised places as a mixture of truth and fantasy which brings out different images and 
interpretations of these places. Said also states that the Orient as a term which was invented by the Europeans had always been described as a "place of romance, exotic beings, haunting memories and landscapes, remarkable experiences (Said, 1979, p. 1). Ondaatje subscribes to this view by Said and accordingly Running in the Family opens with a quote;

"I saw in this island fowls as big as our country geese having two heads... and other miraculous things which I will not here write of." Oderic (Franciscan Friar, $14^{\text {th }}$ century) (Ondaatje, 1982, p. 9)

This quoted epigraph clearly demonstrates how the European travellers perceived the island and how they made a real Eastern country into a mythical land. Additionally, Ondaatje quotes some more views constructed by Europeans who had been to Sri Lanka;

"The roads are intensely picturesque. Animals, apes, porcupine, hornbill, squirrel, pidgeons, and figurative dirt! From the journals of Edward Lear in Ceylon, 1875

"Ceylon is an experience - but heavens, not a permanence." D.H. Lawrence "All jungles are evil." Leonard Woolf (Ondaatje, 1982, p. 78)

Through these quotes, Ondaatje depicts how the colonisers have distorted the truths about the colonised island and how the history of Sri Lanka has been misrepresented by Eurocentric ideology. In a stark contrast to Woolf's view, some other visitors describe Ceylon as a heavenly island; "From Seyllan to Paradise is forty miles, [...] the sound of the fountains of Paradise is heard there" (Ondaatje, 1982, p. 81). All these contrasting Eurocentric views, which are both prejudiced and stereotyped, engender the formation of multiple histories and interpretations which are wholly subjective. What is more, Ondaatje, an insider who was born and lived in Sri Lanka until he was eleven and an outsider who had not been to his homeland for twenty five years, is empowered by this ambivalence to reconstruct the island's history from his own view. Even long before Europeans were tempted by the island, various nations had occupied Ceylon and Ondaatje chronicles the island's colonial history;

The island seduced all of Europe. The Portuguese. The Dutch. The English. And so its name changed, as well as its shape - Serendip, Ratnapida ("island 
of gems"), Taprobane, Zeloan, Zeilan, Seyllan, Ceilon and Ceylon - the wife of many marriages, courted by invaders who stepped ashore and claimed everything with the power of their sword or bible or language. (Ondaatje, 1982, p. 63)

With the domination of different nations, Ceylon's history has been rewritten and reconstructed as its name, language, religion and even its shape changed. By quoting and presenting fantasies of the colonisers and some historical facts about the colonial past of the island, Ondaatje blurs the borders between fact and fantasy or history and fiction

\section{Conclusion}

To conclude, new historicists assert that as it is impossible to find out a single objective truth, history is not a grand narrative. However, they do not reject the grand narrative as an idea completely, yet what they reject is the objectivity of grand narrative which ultimately brings out the totalisation. Furthermore, new historicism highlights the blurred line between public and private histories both of which shape and reshape one another. Therefore, subjective reconstructions and representations of multiple truths or histories which are based on memory, gossip, rumour, power, and discourse emerge due to the link between public and private histories.

It is conclusive that the memoir where Ondaatje tries to document his own private history and Sri Lanka's colonial past, clearly displays the problematic essence of representations of history or multiple histories by recollecting various forms of the past incidents by focusing on both his own and other characters' memories and perspectives. Therefore, it highlights that history which is constructed by humans can be deconstructed and reconstructed. By writing "a well told lie is worth a thousand facts" (Ondaatje, 1982, p. 206) Ondaatje undermines the objectivity of history and adopts a polyphonic reflexivity. He also underlines that as knowledge is constructed discursively or ideologically, the meaning that is embedded in the novel is unsteady. 
Peer-review: Externally peer-reviewed.

Conflict of Interest: The author has no conflict of interest to declare.

Grant Support: The author declared that this study has received no financial support.

Hakem Değerlendirmesi: Dış bağımsız.

Çıkar Çatışması: Yazar çıkar çatışması bildirmemiştir.

Finansal Destek: Yazar bu çalışma için finansal destek almadığını beyan etmiştir.

\section{References}

Adams, T. (2000). Light Writing and Life Writing: Photography in Autobiography. New York: University of North Carolina Press.

Barry, P. (2009). Beginning Theory: An Introduction to Literary and Cultural Theory. Manchester and New York: Manchester University Press.

Bladek, M. (2012). The Place One Had Been Years Ago: Mapping the Past in Michael Ondaatje's Running in the Family. Life Writing, 9(4), 391-406.

Bolton, M. (2008). Michael Ondaaatje's 'Well-Told-Lie': The Ethical Invitation of Historiographic Aesthetics. Prose Studies: History, Theory, Criticism, 30(3), 221-242.

Booker, M. K. (1996). A Practical Introduction to Literary Theory and Criticism. New York: Longman Publishers. Brannigan, J. (1998). New Historicism and Cultural Materialism. London: Macmillan Press.

Davis, R. G. (1996). Imaginary Homelands Revisited in Michael Ondaatje's Running in the Family. English Studies, 77(3), 266-274.

Foucault, M. (1986). The Discourse on Language. In H. Adams \& L. Searle (eds.), Critical Theory Since 1965 (pp.

148-162). Tallahassee: Florida State UP.

Foucault, M. (1991). The Order of Things: An Archaeology of the Human Sciences. London: Routledge.

Foucault, M. (1995). Discipline and Punish: The Birth of the Prison. New York: Vintage Books.

Greenblatt, S. J. (1990). Learning to Curse: Essays in Early Modern Culture. New York and London: Routledge.

Gudmundsdottir, G. (2003). Borderlines: Autobiography and Fiction in Postmodern Life Writing. New York: Rodopi.

Guerin, W. L. (2011). A Handbook of Critical Approaches to Literature. New York and Oxford: Oxford University Press.

Huggan, G. (1995). Exoticism and Ethnicity in Michael Ondaatje's Running in the Family. Essays on Canadian Canadian Writing, 57, 116-127.

Hutcheon, L. (1988). A Poetics of Postmodernism: History, Theory, Fiction. New York: Routledge.

Montrose, L. (2000). Professing the Renaissance: The Poetics and Politics of Culture. In J. Rivkin, \& M. Ryan (Eds.), Literary Theory: An Anthology (pp. 776-785). Oxford: Blackwell Publishing.

Ondaatje, M. (1982). Running in the Family. Toronto: McClelland and Stewart. 
Said, E. (1979). Orientalism. New York: Vintage.

Said, E. (2000). Invention, Memory, and Place. Critical Inquiry 26, 175-192.

Solecki, S. (2003). Ragas of Longing: The Poetry of Michael Ondaatje. Toronto: University of Toronto Publishing.

Smyth, W. J. (2006). Map-Making, Landscapes and Memory: A Geography of Colonial and Early Modern Ireland. Indiana: University of Notre Dame Publishing.

Tyson, L. (2006). Critical Theory Today: A User-Friendly Guide. New York: Routledge.

Zivkovic, M. (2004). Memory and Place in Michael Ondaatje's Running in the Family. Linguistics and Literature, 11, 97-109. 